\title{
Analysis of Financial Statements Based on Financial Ratio and Vertical- Horizontal Method in PT Unilever, Tbk, 2016-2017 Period
}

\author{
Nova Tri Anggraini \\ Mulawarman University, Samarinda, East Kalimantan, Indonesia \\ Email: novatrianggraini8@gmail.com
}

\begin{tabular}{|c|c|}
\hline ARTICLE INFO & BSTRACT \\
\hline $\begin{array}{l}\text { Received: } 05-01-2022 \\
\text { Revision: } 13-01-2022 \\
\text { Received : } 18-01-2022\end{array}$ & $\begin{array}{l}\text { This research aims to horizontally and vertically determine the } \\
\text { financial performance of PT Unilever, Tbk, especially by observing } \\
\text { the development of assets and financial statements through the }\end{array}$ \\
\hline $\begin{array}{l}\text { Keywords: } \\
\text { Financial statement; } \\
\text { financial ratio; vertical } \\
\text { method; horizontal } \\
\text { method }\end{array}$ & $\begin{array}{l}\text { calculation of financial ratios. Based on the research results, it can } \\
\text { be observed that based on the analysis of the ratio of Liquidity, } \\
\text { Profitability and Leverage tend to fluctuate. The liquidity ratio has } \\
\text { increased, Profitability ratio has increased in GPM and NPM but } \\
\text { decreased in Cash Ratio, ROA, and ROE. The Leverage Ratio has } \\
\text { decreased; thus, the financial performance of PT Unilever, Tbk } \\
\text { has not been fully optimal. Based on the horizontal analysis, it can } \\
\text { be concluded that the balance sheet and income statement of PT } \\
\text { Unilever, Tbk are optimal. Based on the vertical analysis, it can be } \\
\text { concluded that the balance sheet and income statement index of } \\
\text { PT Unilever, Tbk are optimal. }\end{array}$ \\
\hline
\end{tabular}

\section{Introduction}

The main problem faced in Indonesia within the PT Unilever must have good management and acquire support from the government and the community to establish a safe corporate economic environment. Presuming that PT Unilever can maintain the company's financial value stability, investors will surely compete to invest their capital in the company. For this reason, investors will focus closely on the financial performance of PT Unilever.

Financial performance describes the company's financial condition in a certain period, both in terms of raising funds and distributing funds, which are usually measured by indicators of capital adequacy, liquidity, and profitability (Andres, 2013). Capital adequacy can be calculated using the Capital Adequacy Ratio (CAR), where this ratio shows the company's ability to handle the risk of losses that may occur to the company (Cashmir, 2016). Liquidity is an analysis of the company's ability to meet its shortterm obligations (Djaja, 2018). Meanwhile, profitability is a comparison ratio used to determine the company's ability to earn profits from sales, assets, and equity, which is based on certain measurement bases (Djaja, 2018).

Nowadays, one of the most serious issues facing financial institutions is fraud in commercial transactions, which has resulted in many companies losing hundreds of billions of dollars (Rashid, 2018). Financial report preparation training had little impact on entrepreneurial performance (Hendiarto, 2021). Furthermore, financial liquidity

\footnotetext{
How To Cite: Anggraini, N. T., (2022). Analysis of Financial Statements Based on Financial Ratio and Vertical-Horizontal Method in PT Unilever, Tbk, 2016-2017 Period. Journal of Social Science, 3(1) https://doi.org/10.46799/jss.v3i1.293

E-Issn: 2721-5202

Published By: Ridwan Institut
} 
ratios influence financial statement fraud, although profitability and leverage ratios have not been demonstrated to affect financial report fraud (Izzalqurny, 2019). Thus, financial stament analysis is rquired to avoid those problems

Financial statement analysis is the process of using financial and analytical tools to explore and comparison with the financial statement for te purpose of making business decision (Abu, 2020). Moreover, financial statements contain essential data that should be used to aid in decision-making (Van \& Carraher, 2013).

Analysis of financial performance has been studied by Nufus (2020) that analyze the level of health, growth, and business prospects of the employess of the PT. X Cooperative. Moreover, Shala, Prebreza, and Ramosaj, (2021) examines the raw data from Samsung Enterprise's financial statements, which includes a horizontal and vertical analysis of the balance sheet and SAP for the years 20152015 and 2017-2018. In addition, the purpose of this study is to discover about PT. Unilever Indonesia Tbk's financial performance from 2012 to 2016 utilizing vertical and horizontal analysis (Lakada, Lapian, Tumiwa, 2017). This current study is different from this research, since this research analyze the finacial performnace use financial ration and vertical-horizontal method.

The problem formulation proposed by the author is: "How are the Financial Statements at PT Unilever in 2017 against the 2016 financial statements based on financial ratio analysis and the horizontalvertical method?"

This research aims to horizontally and vertically determine the financial performance of PT Unilever, Tbk, particularly examining the development of assets and financial statements through the calculation of financial ratios.
The purpose of this research is for the author to comprehend and implement the knowledge gained during

\section{Method}

In this research, an operational formulation or definition will be provided to present a clearer picture of the variables examined.

1. Financial performance referred to in this research is the company's financial condition calculated using the verticalhorizontal method and financial ratios in the financial statements of a company (Sartono, 2002). This method is used to assess the company's financial performance of PT Unilever, Tbk.

2. PT Unilever, Tbk referred to in this research is PT Unilever, listed on the Indonesia Stock Exchange (IDX); thus, it facilitates the researcher to access its financial statements.

\section{Unit of Analysis, Population, and Sample}

1. The unit of analysis of this research is PT Unilever, Tbk, which is listed on the Indonesia Stock Exchange (IDX).

2. The population of this research uses all financial statements of PT Unilever, Tbk starting from 2016 - 2017.

3. The sample used in this research is the balance sheet, profit/loss statement, and cash flow statement of PT Unilever, Tbk.

\section{Analysis Tool}

1. Current Ratio

The following formula can calculate the current ratio:

Current Ratio $=$ Current ASSETS $/$ Current Liabilities

2. Cash Ratio

The following formula can calculate the cash ratio:

Cash Ratio $=$ (Cash+Marketable Securities)/(Current Liabilities)

3. Gross Profit Margin

The following formula can calculate this ratio: 
GPM $=($ Sales-Cost of Good Sold)/Sales

4. Net Profit Margin

The following formula can calculate this ratio:

$\mathrm{NPM}=($ Net Income $) /$ Sales

5. Return On Assets(ROA)

ROA can be calculated using two formulas as follow.

$\mathrm{ROA}=($ Net Income)/(Total Assets)

6. ROE can be calculated with : $\mathrm{ROE}=($ Net Income)/(Net Worth)

7. Debt to Total Assets Ratio

This ratio can be calculated with the following formula.

DAR $=($ Total Debt $) /($ Total Assets $)$

8. Debt to Equity Ratio

This ratio can be calculated with the following formula.

DER $=($ Total Debt)/(Total Equity)

9. Horizontal Analysis

Horizontal analysis is an analysis

conducted by comparing financial

statements for several periods (Mapantau,

2012). This analysis determines the development of the ups and downs of components in the financial statements; it will show the company's development from one period to another.

10. Vertical analysis is an analysis carried out on only one financial statement period (Mapantau, 2012). This analysis calculates the percentage of the elements in the balance sheet to total assets and the elements in the income statement to total income.

\section{Results And Discussion \\ General Overview of the Company}

Unilever Indonesia has been an integral part of the retail market in Indonesia for more than 80 years since it was first established on 5 December 1933. The company has grown to become one of the leading companies in the Fast-moving Consumer Goods category in Indonesia.

The company has nine factories located in the industrial areas of Jababeka, Cikarang, and Rungkut, Surabaya, and has moved its head office to Bumi Serpong Damai. On 3 hectares land, this speciallybuilt new head office is occupied by more than 1,400 of our employees. The company's products, consisting of 39 leading brands and approximately 1,000 Stock Keeping Units (SKU), are marketed through a network involving more than 800 independent distributors that span hundreds of thousands of stores throughout Indonesia.

\section{Analysis}

1. Current Ratio

\begin{tabular}{ccc}
\hline Year & Current Ratio & \% \\
\hline 2016 & 0,605632 & 60,563 \\
\hline 2017 & 0,633693134 & 63,369 \\
\hline 2. Cash Ratio & &
\end{tabular}

\begin{tabular}{ccc}
\hline Year & Cash Ratio & $\%$ \\
\hline
\end{tabular}

\begin{tabular}{ccc}
2016 & 0,03436592 & 3,4366 \\
\hline 2017 & 0,032299248 & 3,2299 \\
\hline GPM & & \\
& & \% \\
\hline Year & GPM & 51,079 \\
\hline 2016 & 0,510791254 & 51,499 \\
\hline 2017 & 0,514985714 &
\end{tabular}

\begin{tabular}{lll}
\hline Year & NPM & \% \\
\hline 2016 & 0,159552473 & 15,955 \\
\hline 2017 & 0,169995032 & 17,000 \\
\hline ROA & & \\
\hline
\end{tabular}

\begin{tabular}{lll}
\hline Year & ROA & \% \\
\hline 2016 & 0,381630742 & 38,163 \\
\hline 2017 & 0,370486036 & 37,049 \\
\hline ROE & &
\end{tabular}

\begin{tabular}{llr} 
Year & ROE & \% \\
\hline 2016 & 1,358486716 & 135,85 \\
\hline 2017 & 1,353960306 & 135,4 \\
\hline DAR & &
\end{tabular}

\begin{tabular}{ccc}
\hline Year & DAR & \% \\
\hline 2016 & 0,719076575 & 71,908 \\
\hline 2017 & 0,726368614 & 72,637 \\
\hline DER & & \\
\hline Year & DER & \% \\
\hline 2016 & 2,5596889 & 255,97 \\
\hline 2017 & 2,654551524 & 265,46 \\
\hline
\end{tabular}




\section{Discussion}

1. Liquidity

a. Current Ratio

The current ratio shows the ability of PT Unilever, Tbk to settle debts that current ASSETS must meet. This ratio shows that every Rp.1.00 of current debt is guaranteed by Rp. 0.60563 current ASSETS of 2016 and Rp.0.63369 current ASSETS of 2017.

b. Cash Ratio

The Cash Ratio shows the ability of PT Unilever, Tbk to meet current debts by using cash and securities at the bank. This ratio shows that every Rp.1.00 of current debt is guaranteed by Cash of Rp.223 in 2016, Rp.214 in 2017.

2. Profitabilitas

a. Gross Profit Margin

Gross profit margin percentage shows that PT. Unilever owns $0.420 \%$ of the revenue. This percentage has increased; in other words, the company's finances have been running optimally.

b. Net Profit Margin

Net profit margin percentage shows that PT. Unilever owns $1.405 \%$. This percentage has increased; in other words, the company's finances have been operating optimally. The higher the NPM value indicates that the company is more efficient in its operations (Sawir, 2014). The company can reduce unnecessary costs; thus, the company can maximize the net profit obtained.

c. Return On Asset

Return On Assets explains the results obtained from the investment made by the company in total ASSETS (Sawir, 2014). From the analysis results, this ratio decreased from 2016 to 2017 by $0.420 \%$, due to profit before tax decreasing by $0.340 \%$.

d. Return On Equity

Return On equity provides an overview of the company's ability from its capital to generate profits for shareholders (Sawir, 2014). From the analysis results, this ratio has decreased from 2016 to 2017. The decrease was due to profit before interest and taxes, which increased from 2016 to 2017 by $0.34 \%$, and the own capital was stagnant.

3. Leverage

a. Debt Ratio on Asset

Total Debt to Total Asset Ratio shows how much the company's ASSETS is financed by debt or how much of the total ASSETS is spent with total debt (Hery, 2018). From the analysis results, it can be observed that the debt ratio has increased from 2016 to 2017 by $0.729 \%$, due to the total debt increased by $0.730 \%$ because income tax payables increased by $0.360 \%$.

b. Debt to Equity Ratio

Debt to Equity Ratio shows the ability of the bank's capital that can be used as collateral for the entire debt (Hery, 2018). From the analysis results, this ratio has increased from 2016 to 2017 by $9.490 \%$, caused by increasing total debt by $0.730 \%$. Meanwhile, equity from 2016 to 2017 decreased by $0.730 \%$ due to a decrease in general reserves, which decreased by $0.01 \%$.

4. Financial Performance Evaluation of PT Unilever, Tbk

a. Based on Financial Ratio Analysis

In terms of liquidity, it can be observed from the Current Ratio, which has increased by $2.806 \%$; thus, the company can be assumed to be progressing well due to excess funds being used effectively. As for the Cash Ratio, it decreased by $0.207 \%$; it can be assumed that the company is not effective in managing its cash due to the decline in the value of cash.

In terms of profitability, it can be noticed that Gross Profit Margin and Net Profit Margin have increased. The respective increase in GPM of $0.420 \%$ 
and NPM of $1.045 \%$ prove that the company's profit will increase because it has been good at managing its operational finances.

In terms of leverage, it can be noticed that the company does not observe its finances properly because each debt ratio increases, which causes the company's finances to be vulnerable.

b. Based on Horizontal Analysis

When viewed from the data, it was identified that the index on the 2016 to 2017 balance sheet tended to show a significant increase. From 2016 towards 2017, the index of ASSETS, liabilities, and equity increased significantly. This means that the balance sheet of PT Unilever, Tbk was optimal.

According to the index data obtained in the income statement, it can be observed that yearly revenue tended to be stable and increased from 2016 to 2017. Thus, it can be concluded that the financial performance of PT Unilever, Tbk was optimal.

c. Based on Vertical Analysis

From PT Unilever's vertical analysis table, it can be observed how the index increases for each asset and liabilities owned by the company. It can be seen that the total ASSETS, liabilities, and equity obtained increased from 2016 - 2017. As for the smallest ASSETS during two years originated from taxes. From the liabilities side, the largest amount of liabilities originated from bank loans. The biggest contribution to equity is unreserved profit.

When viewed from the income statement, PT Unilever has a very fluctuating index number. PT Unilever's revenue has increased significantly yearly, and the bank's total revenue is greater than the total expenses; this means that PT Unilever's financial performance is optimal.

\section{Conclusion}

Based on the analysis, the ratio of Liquidity, Profitability, and Leverage tends to fluctuate. The liquidity ratio has increased, Profitability ratio has increased in GPM and NPM but decreased in Cash Ratio, RO A, and ROE. The Leverage Ratio has decreased; thus, the financial performance of PT Unilever, Tbk is not yet fully optimal.

Based on the horizontal analysis, it can be concluded that the balance sheet and income statement of PT Unilever, Tbk are optimal.

Based on the vertical analysis, it can be concluded that the balance sheet index and the income statement of PT Unilever, Tbk are optimal.

\section{References}

Abu Talha Al-Ansari, A. A. (2020). Financial Statement Analysis of Grameenphone Limited. Google Scholar

Andres, M. (2013). Analisis Laporan Keuangan dalam Mengukur Kinerja Keuangan pada PT. Hanjaya Mandala Sampoerna Tbk. Jurnal EMBA: Jurnal Riset Ekonomi, Manajemen, Bisnis Dan Akuntansi, 1(3). Google Scholar

Cashmir. (2016). Analisis Laporan Keuangan . Jakarta: PT Raja Grafindo Persada.

Djaja, I. (2018). All About Corporate Valuation. Jakarta: PT Gramedia.

Hendiarto, R. S. (2021). The Influence of Training on Financial Statement Preparation on Entrepreneurship Performance. Turkish Journal of Computer and Mathematics Education (TURCOMAT), 12(4), 754-763. Google Scholar 
Hery. (2018). Analisis Laporan Keuangan Integrated and Comprehensive Edition . Jakarta: PT Gramedia.

Izzalqurny, T. R., Subroto, B., \& Ghofar, A. (2019). Relationship between Financial Ratio and Financial Statement Fraud Risk Moderated by Auditor Quality. International Journal of Research in Business and Social Science (2147-4478), 8(4), 34-43. Google Scholar

Lakada, M. N., Lapian, S. J., \& Tumiwa, J. R. (2017). Analyzing The Financial Statement Using Horizontal-Vertical Analysis To Evaluating The Company Financial Performance Period 2012-2016 (Case Study at PT. Unilever IndonesiaTbk). Jurnal EMBA: Jurnal Riset Ekonomi, Manajemen, Bisnis dan Akuntansi, 5(3). Google Scholar

Mapantau, S. (2012). Analisis Laporan Keuangan Berdasarkan Metode Vertikal-Horizontal dan Rasio Keuangan untuk Mengevaluasi Kinerja Keuangan Perbankan pada Bank BUMN (Periode 2008-2010). Universitas Hasanuddin. Google Scholar

Nufus, K., Supratikta, H., Muchtar, A., \& Sunarsi, D. (2020). Analysis of Financial Performance: Case Study of PT. X Employee Cooperative. Utopía Y Praxis Latinoamericana, 25(Esp. 10), 429-444. Google Scholar
Rashid, N., Mahmod, M. S., Afthanorhan, A., Endut, W. A., Yaakub, N., Harun, M. H., \& Salleh, S. I. (2018). The responsibilities of financial fraud activities among of auditor in the business organizations. International Journal of Academic Research in Business and Social Sciences, 8(12), 16461651. Google Scholar

Sartono, A. (2002). Manajemen Keuangan : Teori dan ApliCashi, Jilid 4. Yogyakarta: BPFE.

Sawir, A. (2014). Analisis Kinerja Keuangan dan Perencanaan Keuangan Perusahaan . Jakarta: PT Gramedia. Google Scholar

Shala, B., Prebreza, A., \& Ramosaj, B. (2021). Horizontal and Vertical Analysis of SAMSUNG Enterprise for the Years 2015-2016 and 20172018. Journal of Economics and Management Sciences, 4(1), p50p50.Google Scholar

Van Auken, H., \& Carraher, S. (2013). Influences on frequency of preparation of financial statements among SMEs. Journal of Innovation Management, 1(1), 143. Google Scholar

\section{Copyright holder:}

Nova Tri Anggraini (2022)

First publication right :

Journal of Social Science

This article is licensed under:

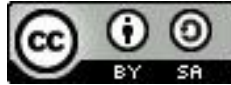

